\title{
FEATURES OF EFFECTIVE CRISIS COMMUNICATION BASED ON PUBLIC RELATIONS PROFESSION RESEARCH.
}

\author{
dr hab. Dariusz Tworzydło', Przemysław \\ Szuba², Marek Zajic ${ }^{3}$
}

\begin{abstract}
The way of conducting communication during the image crisis is a special type of challenge for the company. Lack of preparation of the company for proper communication management may be crucial in averting and/or reducing the effects of crises. The paper presents the results of research conducted among experts from the PR industry and representatives of the largest Polish enterprises from the 500 List compiled by "Rzeczpospolita" daily newspaper. The vast majority of Polish enterprises show an open-minded approach to crisis communication. Companies from oppressive industries, where crises occur more often, are better prepared for crisis communication. The determinants of effective communication in the situation of image threats are, according to the leaders of public relations agencies, anti-crisis preparation, presence of procedures, openness and honesty in communication processes as well as quick response time.
\end{abstract}

Keywords: crisis communication, oppressive industries, anti-crisis immune system of enterprises, public relations, market research

\footnotetext{
1 Dariusz Tworzydło- University of Warsaw, Poland - Head of the Department of Social Communication and Public Relations, Faculty of Journalism, Information and Book Studies at the University of Warsaw. President of the Board of the Institute of the Development of Information Society and Exacto sp. z o.o. Author of over 230 scientific publications, monographs, scripts, articles, and research reports. Former president of the board of the Polish Public Relations Association, and a member of the Public Relations Ethics Council. Advisor and consultant, e-mail:dariusz@tworzydlo.pl 2 Przemystaw Szuba- Exacto, a Ph.D. student at the University of Warsaw, Poland - a graduate in sociology and journalism at The John Paul II Catholic University of Lublin, currently deputy head of the research and strategic analysis department at Exacto sp. z o. o. Author of several dozen research reports and over a dozen scientific articles. In his professional work, he focuses mainly on the analysis of the condition of the public relations industry and research on the PR professionals environment in Poland, e-mail:pszuba@exacto.pl

3 Marek Zajic- Exacto, Poland - a graduate in sociology at The John Paul II Catholic University of Lublin, currently head of the research and strategic analysis department at Exacto sp. z o.o Manager and coordinator of over 350 market and opinion research projects.Author of several dozen research reports. In his professional work, he focuses mainly on aspects related to the management of the external and internal image of the brand, e-mail: mzajic@exacto.pl
} 


\section{Introduction}

The situation of the image crisis is a test for the company. Many factors have an influence on how the company manages the threat. "The crises require from the management boards of the organizations making quick decisions, taking a stand under time pressure and uncertainty, because they are immediately perceived by the external surroundings of the organization (including the media). Everyone is demanding information and urging to take up actions. It is easy then to fall into a panic and make the first decision without thinking about the long-term consequences. It is also easy to be overly sensitive to the escalation of events happening around the organization, regarding the multiplication of decisions and actions, many of which will soon have to be abandoned, because they will be ineffective, and in most cases even harmful." [Wojcik, 2005, p. 592593]. In this situation, the degree of preparation of the company (i.e. actions or negligence that took place) often becomes visible long before the crisis begins. All issues related to the appropriate reaction to the image threat focus on the method of how the organization conducts its communication. There is no good formula that would solve the crisis. There is also no ideal pattern of communication. Nevertheless, it is possible to indicate good practices and a range of errors. However, each time it is necessary to take into account the specificity of the organization, the social and public context, the predispositions of people communicating with the environment or the crisis situation itself [Kaczmarek-Śliwińska, 2015, p. 159]. Bearing in mind that each crisis has its own specific circumstances, it is worth taking a closer look at the guidelines for conducting effective communication during the crisis provided by experts in the public relations industry. The article aims to present the assessments of representatives of the public relations environment based on a set of research results and studies on the characteristics and determinants of conducting effective communication in the course of image threat. The authors seek to answer the question about a set of factors that allow effective communication during a crisis.

\section{The methodology of the research described in the article}

The article employs the results of quantitative research on crisis management public relations. The presented data was collected as part of two independent research projects, which were implemented using the CATI (Computer Assisted Telephone Interview) technique:

- crisis management in the largest Polish enterprises (the research sample constituted the 500 List published by "Rzeczpospolita" daily newspaper). 115 companies took part in the research.

- PR-crisis trends from the perspective of Polish PR agencies, where the respondents were the leaders of the organization. 204 questionnaires were collected, assuming that only one survey could be carried out in one agency.

The above-mentioned research projects cover a very wide set of research areas that are related to crisis management. For the purposes of the article, a set of variables were selected, the analysis of which allows concluding on the level of communicative competence of managers, the role of media in the course of crises and the assessment of the media as a platform on which a large part of crisis situations take place. The research was carried out in 2017 and 2018.

\section{Crisis communication and the oppressiveness of the industry}

Effective crisis communication can be analyzed on many levels and dimensions. Crucial here is to take into account the communication skills of managers working in particular industries of the Polish economic sectors. Interestingly, one of the key factors differentiating the preparation of companies, and hence the competences of managers, is the industry in which the company operates. It turns out that companies operating in 
oppressive industries have more developed communication skills than other entities. Oppressiveness increases the vigilance of managers and people dealing with communication, divisions and departments responsible for public relations. Due to the above, companies subjected to oppressive risk more often have procedures, anti-crisis staff, are more involved in the process of communication training and have more developed structures (spokespersons, managers). The oppressiveness of the industry in which the company operates affects the improvement of the effectiveness of crisis communication activities, which also results from the fact that these companies are more likely than others to undergo crisis situations.

Picture 1. The oppressiveness of the industry

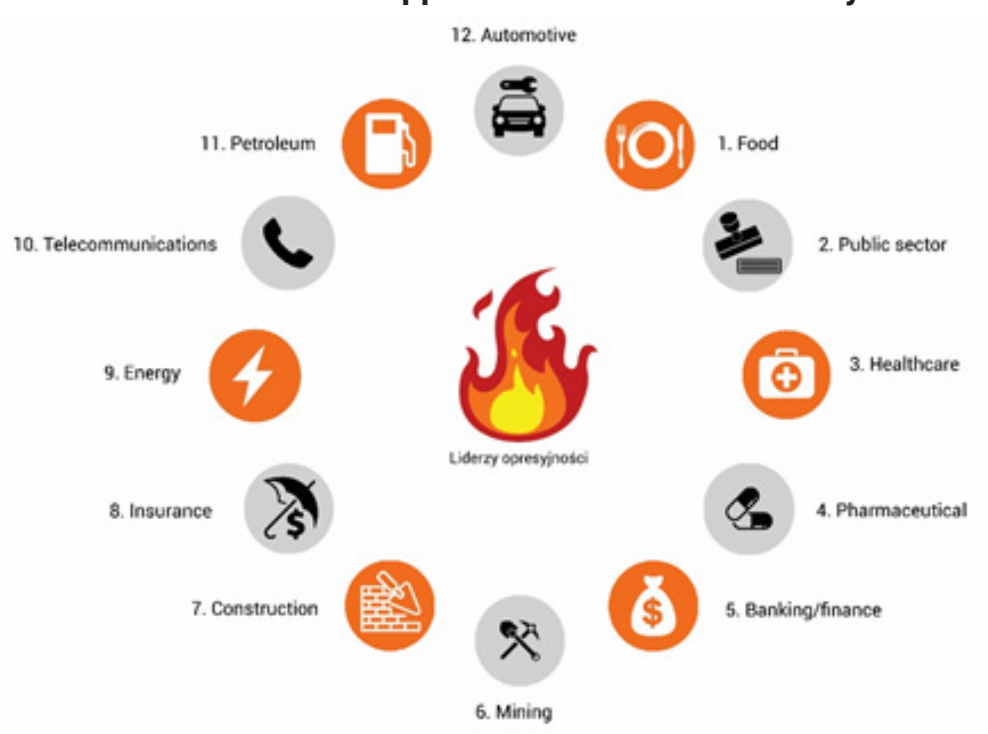

Source: [Tworzydło, Szuba, 2019, pp. 117]

A company operating in the oppressive industry must be aware of the fact that it is particularly vulnerable to external and internal problems. Therefore, it must take actions and make use of tools that will have a positive impact on image security. On the basis of multidimensional research, it was possible to identify 12 industries with a diagnosed higher level of vulnerability to the occurrence of communicational crisis situations [Tworzydło, Szuba, 2019, p. 117].Therefore, the food industry, the public sector and companies conducting medical and pharmaceutical activities should pay special attention to the development of communication skills of their employees and crisis teams.

\section{A model of the anti-crisis corporate immune system of Polish enterprises}

According to the leaders of public relations agencies in Poland, the construction of the corporate immune system should be based primarily on the training aspect (62.3\%), crisis communication manual (61.8\%) and previously conducted audit of existing procedures $(46.6 \%)$. Among the media relating aspects preparing the organization for crises, almost $2 / 5$ of the leaders of the public relations agencies surveyed indicate the need to create an alert system warning about the symptoms of the crisis, e.g. through media monitoring, and $28.4 \%$ of surveyed underline the importance of the press spokesman present in the organizational structures. On the other hand, $27 \%$ of respondents mentioned an established method of maintaining relations with the media (holding statement, statements, Q\&A)possessing by the organization. 
Picture 2. Attributes that simplified preparation for crises

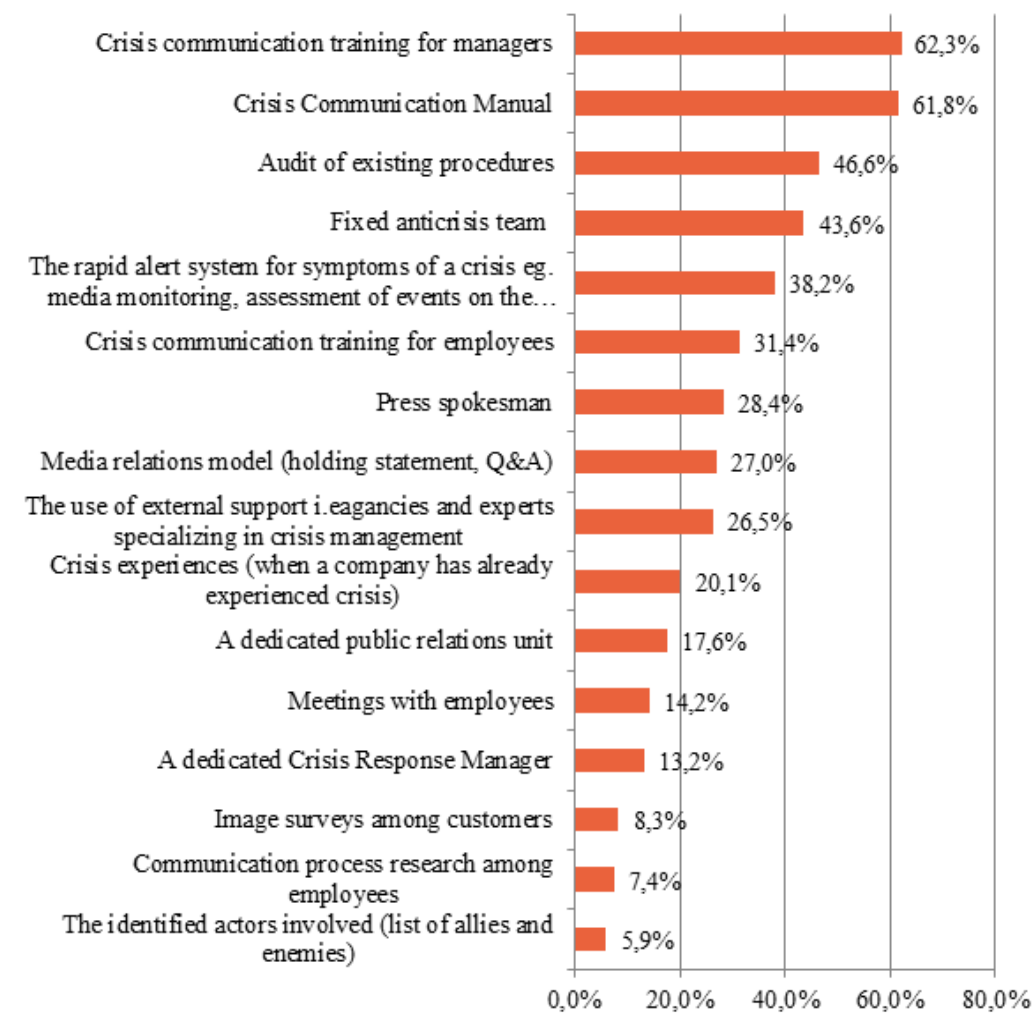

Source: [Tworzydło, Szuba, (in press)]

Once again, it can be seen that the training, according to the PR agencies, is the component of the company's image security. They are part of acquired competencies and should be implemented in the form of, for example, crisis simulation or preparation for speeches before journalists. This is the opinion of experts who deals with crises, However, the practice shows that the aspect of training is not appreciated. Only slightly more than half of the surveyed companies from the 500 List of "Rzeczpospolita" daily newspaper (51\%) indicate that they conduct communication training among their management staff. Companies rely much more on their immune system based on the creation of a crisis manual (83\%). They also, more often invest in their own PR personnel, relevant structures (63\%) and anti-crisis staff (59\%).

Picture 3. The quality of anti-crisis prevention of the largest Polish companies

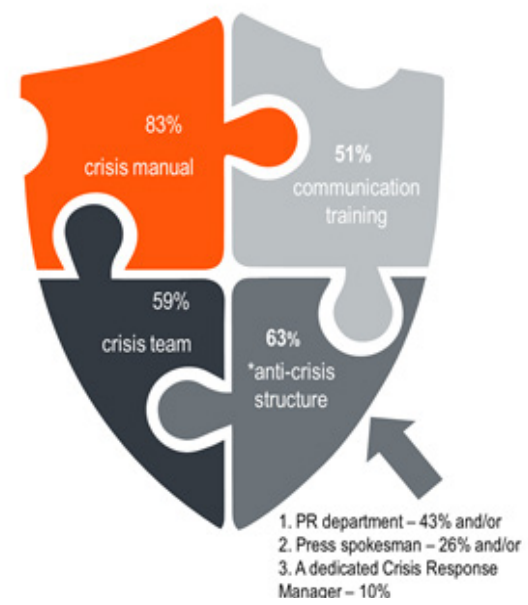

Source: The author's own study based on [Tworzydło, taszyn, Szuba, 2018] 
Analyzing the leaders' opinions of the PR industry one can notice that the construction model of the above-described immune system of the largest Polish companies can be created on the basis of this important crisis experience (unfortunately it is about the negative effects of crises). Preparation for the crisis is related to the development of skills and tools that were established based on the crisis that took place in the company in the past. The preparation of the company for new challenges and crisis risks requires adaptation of the above tools and skills that will allow better readiness for the unknown [Baubion, 2013, p. 12].

It also corresponds with previously analyzed data regarding the phenomenon of oppressiveness, where greater company's contact with crises determines better preparation for their possible re-occurrence. Research on public relations crisis communication shows that only $7 \%$ of PR agency leaders indicate that their clients decide to cooperate with the agency as part of prevention (in the sense of the proverb that prevention is better than cure).Most often, cooperation is undertaken during an image crisis (44\% implements ad hoc solutions) or under the influence of negative consequences of crises $(32 \%)$. The dominance of the strategy of cooperation between the company and the agencies in response to the crisis situation shows that the lack of communication skills during the crisis is primarily caused by the neglect of the companies that are clients of public relations agencies and the delayed reaction[Tworzydło, Szuba, (in press)].

\section{Common features of image crises}

Additional information on the validity of communication aspects is provided by PR industry professionals regarding the subject of existing crises. Two out of three PR agency leaders (65.2\%) believe that image crises have common features. In their opinion, the common denominators are usually disregarding the situation, lack of reaction or delayed reaction (33.1\%). In the second place, they enumerate poor internal and/or external communication (26.3\%). While the first factor can only indirectly arise from media-related competences, such as the lack of media monitoring, or the insufficiently developed network of media relations in terms of quantity and quality, the second common denominator refers directly to communication competences [Tworzydło, Szuba, (in press)].

It is worth bearing in mind that the efficient ability to conduct communication activities - especially on the Internet - is crucial from the point of crisis prevention and control. Over the last decade, the main change that occurred in the etiology of image crises is related to the growing role of the Internet, especially social media. "In 2016, issues occurring on the Internet were the main source of the crisis. In previous years, their impact was much smaller, that is why the factor was not among the three mainly mentioned sources from 2006 and 2009 "[Tworzydło, Łaszyn, Szuba, 2018, p. 66]. Therefore, internal and external communication is one of the strategic areas of crisis management.

\section{Effective communication, what exactly does it mean?}

The key question is, therefore, what kind of specific crisis communication is effective? Representatives of the public relations community in their answer indicate three characteristics: prepared, honest and quick. The relatively largest number of PR leaders responded that the most critical determinant of the effectiveness of crisis communication is anti-crisis preparation and the presence of procedures (30\%).This means that, according to practitioners, it is better not to rely on improvised solutions and, if possible, consider scenarios of potential situations that threaten the image of the company. The most frequent answer lies in the area of structural and procedural preparation of the company. 
Picture 4. What should effective crisis communication consist of?

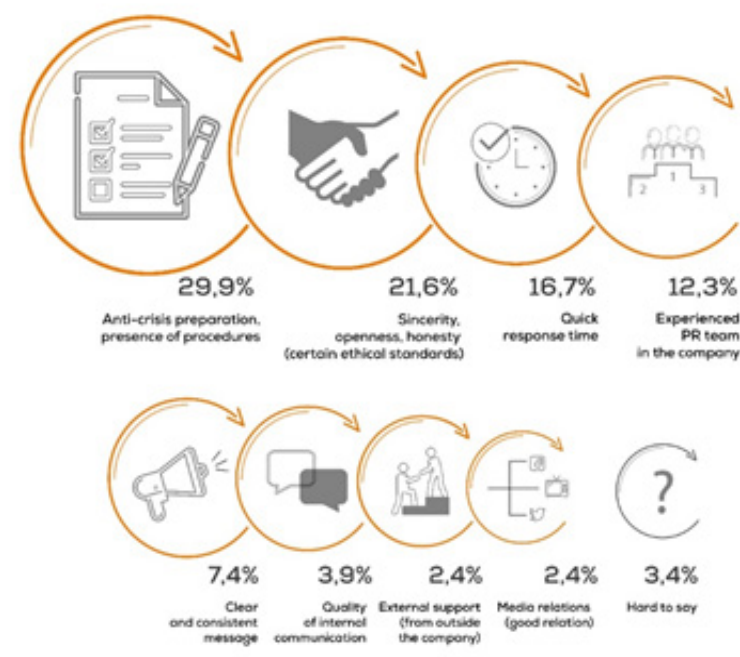

Source: [Tworzydło, Szuba, (in press)]

The second most common response of public relations experts is particularly interesting from the point of view of the features of the messages themselves. Every fifth professional working in the industry mention sincerity, openness, and honesty as the most important factor of crisis communication (22\%). The results of the research are a confirmation of what F.P.Seitel wrote, indicating that the key principle of effective crisis communication is to conduct open and honest communication [F.P. Seitel, 1995, p. 452453]. This response is not only an indication of how to construct messages in a substantive way but also has a strong axiological overtone. It refers to the PR profession as a profession possessing social trust, which places "particularly high demands on people performing it, including ethical requirements. It results from the fact that while working in social communication sector and focusing on $>>$ building trust... $<$, they are subjected to constant observation and evaluation "[Stolarczyk, 2016, p. 75].

According to almost $17 \%$ of PR professionals in crisis communication, quick response time counts. This is particularly important due to the aforementioned trend of the growing importance of the Internet and social media in the spread of the crisis (the media as a platform where crises take place).Appropriately quick response time allows for leveling or at least counteracting the two most frequently cited consequences of a crisis situation, i.e. negative media publications (62\%) and negative criticism in social media (38\%) [Tworzydło, Łaszyn, Szuba, 2018, p. 66].

Among the other factors of effective communication mentioned by PR agency leaders, the most important is the fact that possessing a PR team in the company's structures has been mentioned by $12 \%$ of respondents, and the use of external support only by $2 \%$. It can be connected with the fact that low awareness of clients is one of the biggest concerns of the PR community regarding the functioning of the industry [Tworzydło, Szuba, Zajic, 2017, p. 38-39]. This is another voice in the debate on raising the awareness of the business community regarding the preparation and development of employees within their own structures for cooperation with external professionals.

It is worth looking into the strategies of companies operating in Poland in the context of communication effectiveness. Among the representatives of Polish companies from the 500 List of "Rzeczpospolita" daily newspaper dominates the strategy stating that it is better to rely on cooperation with the media than to apply the strategy of a closed fortress. A seemingly eightfold advantage of the open-minded approach (82\%) on the closed-minded approach (10\%) is a good result. However, if the approach to this results in such a way that every tenth of the largest companies in Poland adopts a strat- 
egy of communication blockade in a crisis situation, there is still much to do in the field of education. If the use of those undesirable communication strategies is noticeable at the level of $10 \%$ among the best, and thus the most developed enterprises in the country, it can be presumed that among less developed enterprises this approach is much more frequent and dominant in some areas.

\section{Models of communication during and after the crisis}

So how to carry out effective crisis communication? The "Basic 5 Principles o Crisis Communication", the solution proposed by Adam Łaszyn, comes with help. According to this approach, the first step is to "feel sorry". This is very important in terms of quick response. Expressing regret because of the event allows the company to show that it is aware of the situation and does not "hide its head in the sand", and in the same time is interested in the event. Of course, it is important to skillfully express regret, especially if it is not certain whether the fault really lies with the company. It allows, however, to take immediate action, which is particularly recommended, because it often rejects accusations of being passive which appear at the time of the image crisis. The second step is to "admit it". It is the most difficult step as it requires taking responsibility if the enterprise is at fault. Admitting the error is difficult for both people and companies, as it shows that something was actually done in a wrong manner. However, it is generally perceived positively because it is associated with apologies, which very often can significantly contribute to the end of the crisis. The next step in the preferred model is "counteract". Of course, in addition to the involvement of measures and resources in the technical solution of the situation, the appropriate behavior of the company's representatives is crucial. It involves, for example, professional treatment of the client, if the matter was just a single occurrence or constant informing the audience about the measures undertaken to defuse the situation. The fourth step is to "improve". In many cases, it boils down to information about actions taken to ensure that a similar situation will not appear. The last step is to "make up for losses". In situations of crises related to the individual customer, it is often a chance to convert the crisis in a positive event for the company. Appropriate preparation of procedures regarding dissatisfaction of the client or a larger group of customers or recipients(in a situation where the company can be blamed) and final compensation of the affected people with an adequate gift can obviate the crisis and even contribute to the creation of positive publicity [Łaszyn, 2011, p. 165-174].

An important issue regarding crisis management is also described in the framework of the post-crisis echo theory. It is connected with the fact that the end of the crisis does not take place when the media stop writing, because they still remember, especially in the case of the Internet. After the first wave of media reports, another, weaker one may come, even in a situation where positive press releases will appear about the company. There will be a recall of all the bad things that happened in the company. The theory of "post-crisis echo" assumes that in practice there is a high probability that each subsequent crisis will recall earlier company's image problems. Therefore, the implementation of in-depth and continuous monitoring of the media, especially aimed at the area in which the crisis took place, will be an important step in the anti-crisis management. In this way, it will be possible to capture potential new post-crisis waves that may be the source of new problems [Tworzydło, 2017, p. 208-209].

\section{Summary}

The largest Polish enterprises in the vast majority present an active approach to crisis situations. Their immune system is based on manuals, organizational structures, own PR experts, and an anti-crisis staff, which are elements highly recommended by the surveyed PR specialists. A clear discrepancy between the guidelines of the public relations community and the practices of the largest Polish companies appears in the case of communication training. Almost two out of three experts say that communica- 
tion training should be the basis of the company's immune system and this is the most frequently suggested recommendation, while such training is conducted only in just over half of the surveyed companies from the 500 List of "Rzeczpospolita" daily newspaper.

Companies operating in the oppressive industries are better prepared for communication management during crises, are more involved in the organization of communication training, and have anti-crisis structures and procedures. This means that actions undertaken during situations of permanent image threat and greater experience because of crises that have occurred before are the main factor influencing the anti-crisis organization of the company. This is connected with the fact that the majority of professionals noticed the establishment of cooperation with entrepreneurs during or after a crisis. The companies' continuous cooperation with public relations agencies as part of crisis prevention is rare.

The main feature of effective crisis communication is experts' anti-crisis preparation and the presence of procedures, openness, and honesty of communication as well as quick response time. Other features related to the communication itself mentioned by PR professionals are clarity and consistency of the message and its quality. Some experts point out that, in the context of effective communication, it is important to have an experienced public relations team. However, in the context of results from other studies, this should be treated as a postulate of improving the quality of cooperation with public relations agencies, rather than recommending companies to deal with situations of image threat on their own.

\section{REFERENCES:}

BAUBION CH. (2013), Strategic Crisis Management, Geneva,OECD.

KACZMAREK-ŚLIWIŃSKA M. (2015),Public relations w zarządzaniu sytuacjami kryzysowymi organizacji. Sztuka komunikowania się, Warszawa,Difin.

ŁASZYN A. (2011), Sztuka Public Relations. Z doświadczeń polskich praktyków,Warszawa, Związek Firm Public Relations.

SEITEL F.P. (1995) The practice of public relations, Englewood Cliffs, New Jersey.

STOLARCZYK A. K. (2016) Etyka w PR - zawód wysokiego zaufania społecznego, [in:] Łaszyn A. Tworzydło D. (ed.), 25 lat. Pierwsze ćwierćwiecze public relations w Polsce, , Warszawa-Rzeszów,Newsline.pl.

TWORZYDŁO D. (2017),Public Relations. Praktycznie, Rzeszów,Newsline.

TWORZYDŁO D., ŁASZYN A., SZUBA P. (2018), Zarządzanie sytuacją kryzysową w polskich przedsiębiorstwach, Rzeszów,Newsline.pl.

TWORZYDŁO D., SZUBA P. (in press), Kryzysowe public relations z perspektywy agencji PR. Analizy tendencje i uwarunkowania, in press.

TWORZYDŁO D., SZUBA P. (2019) Rola profilaktyki antykryzysowej z perspektywy największych polskich przedsiębiorstw oraz agencji public relations na podstawie badań eksperckich, [in:] MINIB, Warszawa, Instytut Lotnictwa, Wydawnictwa Naukowe.

TWORZYDŁO D., SZUBA P., ZAJIC M. (2017), Analiza kondycji branży Public Relation. Raport z projektu badawczego 2017, Rzeszów,Newsline.pl.

WOJCIK K. (2005), Public Relations. Wiarygodny dialog z otoczeniem, Warszawa,Placet. 